\title{
Ghrelin promote partial the early recovery of rats after subtotal gastrectomy
}

\author{
Song Yu, Zhi-Gang Wang, Cheng-Guang Yang, Jun Yan, Wen-Cai Qiu and Qi Zheng*
}

Department of General Surgery, Sixth People's Hospital of Shanghai Jiaotong University, Shanghai 200233, China.

Accepted 12 May, 2011

\begin{abstract}
The aim of this study was to investigate the validity of exogenous ghrelin for early recovery in partial gastrectomied rats and its long-term significance. The subtotal gastrectomy ( $B_{- \text {-type }}$ ) rats were randomly divided into two groups, and then they were treated with intraperitoneal injection of saline or ghrelin intervention respectively. Body weight and daily food intake were measured before and after the operation. After the seventh post-operation, rats were sacrificed, the fundus of stomach and anastomosis were taken to determine ghrelin mRNA expression by real-time fluorescent quantitive PCR and to evaluate the bursting pressure and hydroxyproline content. There was no difference in body weight between the two groups $(P>0.05)$; Cumulative food intake $(P<0.05)$ was $52.50 \pm 6.77 \mathrm{~g}$ in ghrelin group, which was higher than that in the saline group $(45.67 \pm 7.47 \mathrm{~g})(\mathrm{P}<0.05)$. However, the ghrelin mRNA expression in ghrelin treatment group was lower than the control group $(P<0.01)$. Compared to the saline group, ghrelin-treated rats displayed a higher bursting pressure $(P<0.05)$ and anastomotic hydroxyproline content $(P<0.01)$. Ghrelin treatment in the postoperative rats can promote energy metabolism and body weight gain. Ghrelin could effectively promote the healing of anastomosis. However, exogenous ghrelin intervention may inhibit the early compensatory mechanisms of residual stomach.
\end{abstract}

Key words: Ghrelin, subtotal gastrectomy, rats, anastomosis, early recovery.

\section{INTRODUCTION}

The recognized brain-gut peptide hormone ghrelin with 28 amino acids-endogenous intrinsic ligand for the growth hormone secretagogue receptor (GHS-R)-is mainly produced (60 to $70 \%$ ) by X/A cells in the fundic gland of the stomach and a small amount distributed in the small intestine, pancreas, kidney and hypothalamus (Kojima et al., 1999; Date et al., 2000; Hosoda et al., 2000; Dornonville et al., 2001; Rindi et al., 2002; Cowley et al., 2003; Kojima and Kangawa, 2005). The acylation of its Serine-3 is thought to be required for its biological activity (Yang et al., 2008). Ghrelin plays vital physiological activities in food intake, energy homeostasis and body-weight regulation by both endocrine and paracrine/autocrine ways (Wren et al., 2000; Asakawa et al., 2001; Kamegai et al., 2001).

${ }^{*}$ Corresponding author. E-mail: chuner_1122@163.com. Tel: $+86-21-64369181$.
Ghrelin stimulates the growth hormone $(\mathrm{GH})$ release via the GHRH (growth hormone releasing hormone)dependent mechanism acting on the growth hormone secretagogue receptor. Administration of pharmacological doses of ghrelin to intact animals can increase food intake, induces weight gain, this is thought to be independent of GH and mediated primarily by the hypothalamic neuropeptide Y (NPY) and agouti-related protein (AGRP) systems (Dickson and Luckman, 1997; Lall et al., 2001; Shintani et al., 2001; Kohno et al., 2007; Hameed et al., 2009).

Gastrectomy is the predominant therapy for most stomach-associated diseases, including tumors and complex ulcers. Body weight loss is one of the most serious but ubiquitous sequelae of gastrectomy, due to the reduction of food intake because of complain of loss of appetite and decrease of gastric acid (Liedman, 1999; Melissas et al., 2002). In addition, gastrectomized patients are often prone to anastomosis rupture or anastomosis fistula. These can seriously affect the 
Table 1. Primers used in this study.

\begin{tabular}{ll}
\hline Primer $/$ probe & Sequence 5' to 3' \\
\hline rattus beta actin For & 5'-AGAAGATTTGGCACCACACTTTCTA 3' \\
rattus beta actin Rev & 5'-TCTCAAACATGATCTGGGTCATCTT- 3' \\
rattus beta actin Probe & fam-5'-TGAGCTGCGTGTGGCCCCTGAGGAG- 3'-tamra \\
Ghrelin For & 5'-CCATGGTGTCTTCAGCGACTATC- 3' \\
Ghrelin Rev & 5'-GATTCCTTTCTCTGCTGGGCTT- 3' \\
Ghrelin Probe & fam-5'-CCTCAGCATGCTCTGGATGGACATG- 3'-tamra \\
\hline
\end{tabular}

effectiveness of their postoperative recovery and future quality of life. At present, there is no satisfactory mechanistic explanation and treatment for any of these symptoms. Loss of ghrelin could be implicated in these symptoms, since as much as $80 \%$ of circulating ghrelin is lost following surgical removal of the glandular stomach or the acid producing part of the stomach in rats and humans (Ariyasu et al., 2001; Takachi et al., 2006).

TG seems to be compensated for by increased energy intake. Preserved postprandial appetite responses and precocious postprandial fullness seems to be associated with disturbances in gastrointestinal transit of the ingested meal and are likely to be independent of vagal fiber integrity or stomach-released ghrelin (Kamiji et al., 2009). Short-term administration of synthetic ghrelin was safe and successfully lessened postoperative BW loss and improved appetite and food intake after total gastrectomy (Adachi et al., 2010). In this study, we performed the subtotal gastrectomy rats and to study the validity of ghrelin in the early recovery in rats by their food intake and healing of anastomosis.

\section{MATERIALS AND METHODS}

\section{Chemicals and animals}

All experiments were conducted with the approval of the animal ethics committee of the Sixth People's Hospital of Shanghai Jiaotong University, China, and adhered to the ethical guidelines of the Laboratory Animal Care and use committee of the association for research. All effort was made to minimize suffering and the number of animals used in the study. Ghrelin was obtained from Tocris Cookson (Bristol, UK). Mail SD rats were provided by the experimental animal center of Shanghai Academia Sinica. They were maintained on a $12 \mathrm{~h}$ light/dark cycle and given conventional stand food and tap water acclimatized for at least one week and not deprived of food before gastrectomy. They were operated when their body weight was around 200 to $220 \mathrm{~g}$. Before operation, they were fasted overnight with free access to water and recorded their weights.

\section{Subtotal gastrectomy and Billroth I reconstruction}

Rats $(n=12)$ were anesthetized with an intraperitoneal injection of Ketamine $(2 \mathrm{mg} / \mathrm{kg})$ and a median abdominal incision was made with the clean instruments. No antibiotics were used. After the stomach was separated from the greater and lesser omentum, sterile gauze was placed under the stomach. The non-invasive vascular clamps closed proximal stomach and duodenum after the left gastric artery was ligated, the duodenum $3 \mathrm{~mm}$ distal to the pyloric ring and approximately $50 \%$ of the glandular stomach were resected. The remnant stomach and duodenum were anastomosed with a single interrupted layer using 6 to 0 monofilament sutures (Billroth I reconstruction). Before the abdominal closure, the peritoneal cavity was irrigated with $50 \mathrm{ml}$ warm saline solution and checking for the bleeding. The subtotal gastrectomy took approximately $40 \mathrm{~min}$ and less than $1.0 \mathrm{ml}$ of blood loss. The rats were fasted but free of water in the first post-operation, and then they were free of food and water until the seventh post-operation.

\section{Study design}

The Ghrelin group (Gh) rats $(n=6)$ and Saline group (Sa) rats $(n=6)$ received an intraperitoneal injection of ghrelin and saline daily for seven days after the operation respectively. The injection of ghrelin was $10 \mathrm{nmol} / \mathrm{kg}$ body weights. Their daily food intake and daily body weight were measured respectively in $5 \mathrm{pm}$ before and after the gastrectomy.

\section{RNA extraction and real time quantitative RT-PCR}

The expression of ghrelin mRNA was measured by real-time fluorescent quantitative PCR. The rats were killed by decapitation in the seventh post-operation. The fundus of stomach was dissected out (20 to $30 \mathrm{mg}$ ) and immediately frozen in liquid nitrogen and stored at $-80^{\circ} \mathrm{C}$ until analysis. Total mRNA was isolated from rat tissues using $1 \mathrm{ml}$ of Trizol reagent (Invitrogen, USA) and then homogenized. The ghrelin mRNA concentration was determined by spectrophotometry. Real-time quantitative PCR was performed using the applied biosystems steponeplustm Real-time PCR Systems (applied biosystems).All reactions were performed in $50 \mu \mathrm{l}$ and carried out using the following cycling parameters: predenaturation $99^{\circ} \mathrm{C}$ for 5 min and then 40 cycles of $95^{\circ} \mathrm{C}$ for $15 \mathrm{~s}$, $60^{\circ} \mathrm{C}$ for 20 s. A melting curve was produced after each run according to the manufacturer's instructions. The threshold cycle (Ct) was calculated by the instrument's software (Stepone software v2.0) and the relative expression of ghrelin mRNA was calculated. Table 1 shows a list of all the primers searched from Genebank used in this study.

\section{Measurement of bursting pressure}

After the rats were killed by decapitation, the abdominal wound was opened and the anastomosis was identified immediately. The adhesions were carefully dissected and $2 \mathrm{~cm}$ length on each side was excised. The lumen was cleaned by the normal saline solution. The distal side was connected via a pressure transducer with 4-0 

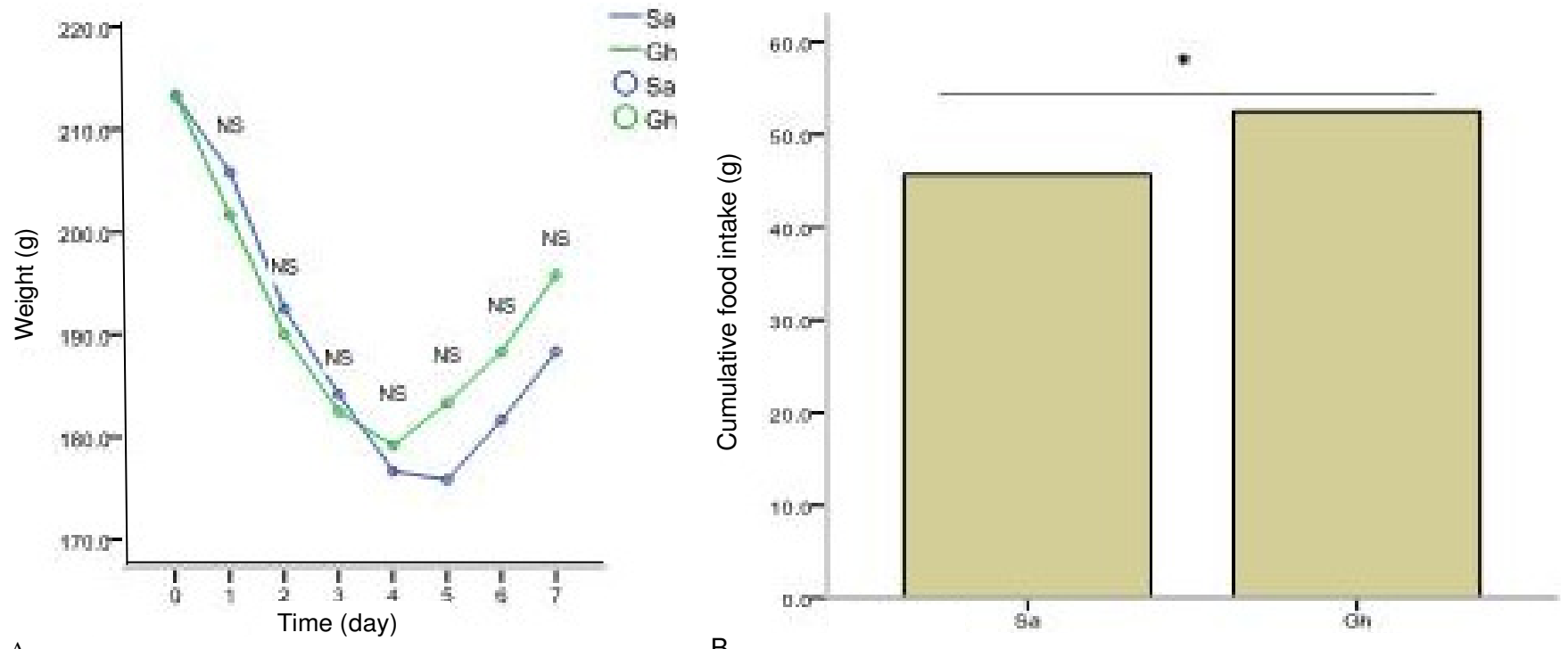

Figure 1. The body weight of ghrelin treated and saline controlled rats after surgery for 1 week (A). The cumulative food intake of Gh rats are more than that in Sa controlled rats (B). NS: no statistically significant. ${ }^{*}<<0.05$.

silk ligated and when the lumen was with a continuous infusion of the normal saline solution at a rate of $2 \mathrm{ml} / \mathrm{min}$ using an infusion pump. Then the pressure in the bowel was monitored and the bursting pressure was recorded on a chart recorder as the maximum pressure achieved during the injection phase. The results were expressed as millimeters of mercury.

\section{Hydroxyproline determination}

After measurement of bursting pressure, each segment was resected at $0.5 \mathrm{~cm}$ on each side of the anastomosis. After the samples were cleaned using the normal saline solution, they were weight and frozen in $-80^{\circ} \mathrm{C}$ until the hydroxyproline determination. Hydroxyproline as an expression of collagen deposition was determined under $450 \mathrm{~nm}$ wavelength spectrophotometer and calculated with the stand curve.

\section{Statistical analysis}

Statistical analysis was performed using the SPSS version 18.0 software package (SPSS, Chicago, USA). All data were expressed as mean \pm standard deviation for body weight, cumulative food intake, ghrelin mRNA expression, bursting pressure and hydroxyproline content. Student's paired t test was used to the comparison between groups. A $p$ value of $<0.05$ was considered statistically significant.

\section{RESULTS}

\section{Body weight and cumulative food intake}

The body weight in Gh rats was lower than in Sa rats, continuing until 3 days after surgery. From the forth operative day the weights of two groups were all increased and the weights of $\mathrm{Gh}$ rats were higher than in $\mathrm{Sa}$ rats. Daily injection of ghrelin to $\mathrm{Gh}$ rats raised body weight $(195.83 \pm 7.36 \mathrm{~g})$ compared with the saline treated control rats $(188.33 \pm 7.53 \mathrm{~g})$ in the seventh post-operation, but there was no statistically significant $(p>0.05)$ (Figure 1A). Cumulative food intake which was expressed as g/individual over time in $\mathrm{Gh}$ rats was $52.50 \pm 6.77 \mathrm{~g}$, higher than $45.67 \pm 7.47 \mathrm{~g}$ in Sa rats $(p<0.05)$ (Figure 1B).

\section{Ghrelin mRNA levels in rats stomach}

As shown in Figure 2, the expression of ghrelin mRNA in ghrelin treated rats was $0.08 \pm 0.04$, which was significant lower than that of $0.22 \pm 0.68$ in the saline control groups $(p<0.01)$.

\section{Bursting pressure and hydroxyproline content}

From Table 2, we can conclude that the bursting pressure of anastomosis in Sa rats was $155.83 \pm 6.62$ $\mathrm{mmHg}$, which was lower than that of $172.33 \pm 10.44$ $\mathrm{mmHg}$ in $\mathrm{Gh}$ rats $(p<0.05)$. Hydroxyproline content in ghrelin treated rats after gastrectomy was $0.50 \pm 0.29$ $\mu \mathrm{g} / \mathrm{mg}$ wet tissue, which was significant higher than that of $0.43 \pm 0.48 \mu \mathrm{g} / \mathrm{mg}$ wet tissue in the saline control rats $(p<0.01)$.

\section{DISCUSSION}

As the endogenous ligand for the growth hormone 


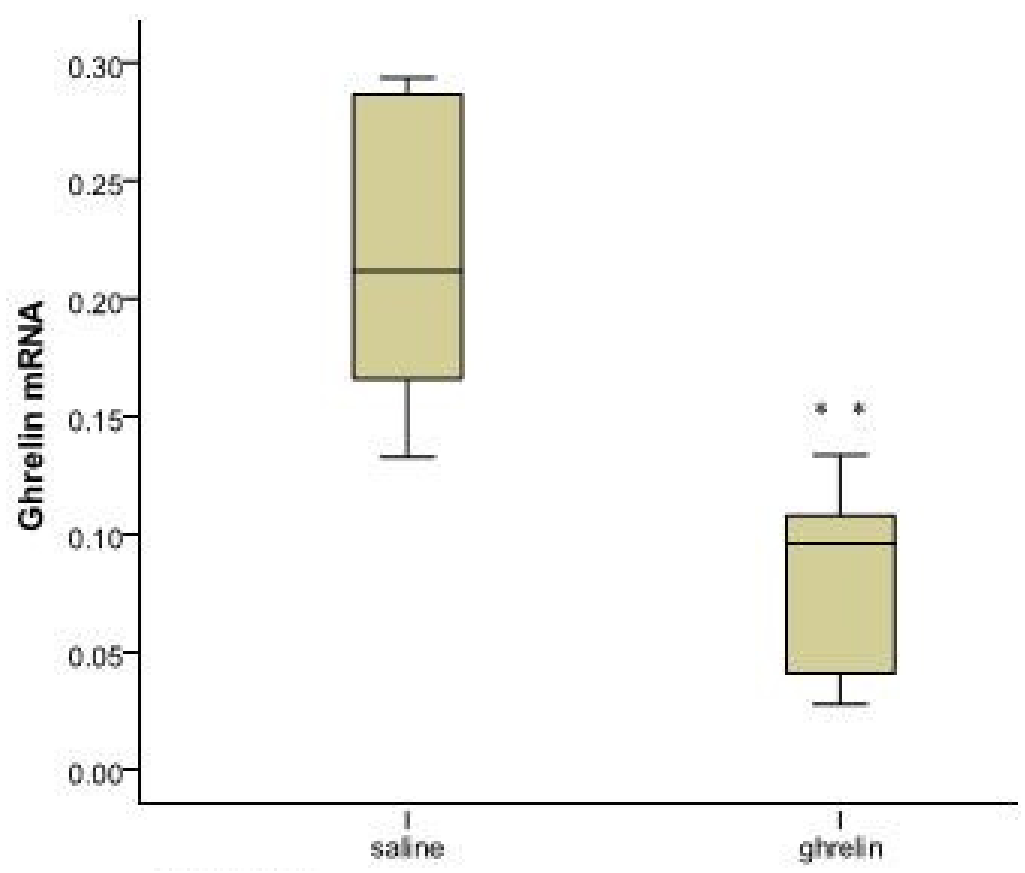

Figure 2. The expression of ghrelin mRNA in ghrelin treated rats was $0.08 \pm 0.04$, which was significant lower than $0.22 \pm 0.68$ in saline controlled groups $(P<0.01)$.

Table 2. Bursting pressure and hydroxyproline content of anastomosis in seventh post-operation.

\begin{tabular}{lcc}
\hline Group & Bursting pressure $(\mathrm{mmHg})$ & Hydroxyproline content $(\boldsymbol{\mu g} / \mathbf{m g}$ wet tissue) \\
\hline Sa rats & $155.83 \pm 6.62$ & $0.43 \pm 0.48$ \\
Gh rats & $172.33 \pm 10.44^{*}$ & $0.50 \pm 0.29^{* *}$ \\
\hline
\end{tabular}

${ }^{*}: p<0.05 . *$ : $p<0.01$.

secretagogue receptor (GHSR), ghrelin has played an multiple physiologic processes including the regulation of pituitary hormone secretion, energy homeostasis and gastrointestinal activity by both endocrine and paracrine/anticrime ways (Kojima et al., 1999; Kojima et al., 2004). Ghrelin administration leads to weight gain in expimental animals by stimulating food intake, decreasing energy expenditure and spontaneous activity, and promoting adipogenesis (Choi et al., 2003; TangChristensen et al., 2004). It mediated primarily by the hypothalamic neuropeptide Y (NPY) and agouti-related protein (AGRP) systems (Cowley et al., 2003; Toshinai et al., 2003). The previously reported that plasma ghrelin levels eredecreased after subtotal gastrectomy (Wang et al., 2008). Exogenous ghrelin treatment could increase food intake and body weight (Dornonville et al., 2005) and increase the expression of the orexigenic peptides NPY and AgRP and decreased the expression of the anorexigenic peptide POMC in the arcuate nucleus (Egecioglu et al., 2008).
Our finding that administration of exogenous ghrelin could effectively increase food intake in the early postoperation after subtotal gastrectomy. Ghrelin increased the body weight although it was still lower than that of pre-operation. The body weight of ghrelin treatment was lower until the third post-operation, which was in adverse increased higher from the forth post-operation. We also found that ghrelin administration could be down-regulated ghrelin mRNA expression in residual fundic gland of the stomach. Previous reports showed that ghrelin could be released from extra-stomach tissues such as duodenum and pancreas and play a compensatory role after gastrectomy and ghrelin treatment in later periods could be effective in treating patients with gastrectomy-induced anorexia and associated symptoms (Takachi et al., 2006; Koizumi et al., 2010). So we can preliminary conclude that exogenous ghrelin treatment after gastrectomy could increase food intake and body weight, but maybe inhibit the early compensatory role in the residual stomach.

The further study is needed that there are other 
inhibitions in the early post-operation to the compensatory roles of other organizations such as the pancreas, ileum with ghrelin treatment or not. Anastomotic disruptions or leakages have long been one of the most disastrous consequences leading to either high morbidity or mortality. Bursting pressure and collagen content are the two major parameters of anastomotic healing. Bursting pressure demonstrate mechanical healing of anastomosis (Hingh et al., 2002; Thornton and Barbul, 1997). Collagen is the major structural protein providing biomechanical strength to anastomosis and determining early anastomotic resistance. The content of hydroxyproline could represent collagen metabolism, which is stability contain in collagen protein. Therefore, we evaluated bursting pressure and hydroxyproline content as two indicators of anastomotic healing.

Endocrine of growth hormone $(\mathrm{GH})$ is regulated mainly by GH-releasing hormone $(\mathrm{GHRH})$, ghrelin, and somatostatin (SS) (Hataya et al., 2001). Exogenous ghrelin potently stimulates pituitary $\mathrm{GH}$ release. $\mathrm{GH}$ promotes wound healing by way of fibroblast acceleratedproliferation, inhibiting the bleeding of ulcer and increasing blood concentrations of arginine and glutamine from skeletal muscle. Inflammation is another inevitable factor of successful wound healing. Ghrelin may also have antiinflammatory roles to promote wound healing by enhancing immune cell proliferation and inhibiting secretion of proinflammatory cytokines from immune cells (Dixit et al., 2004; Dixit and Taub, 2005). However, there are still controversies (Zhao et al., 2006). In addition, ghrelin also play the role on increasing submucosal perfusion to protect the mucosal (Brzozowski et al., 2006; Konturek et al., 2007). In our present study, ghrelin intervention could effectively increase the bursting pressure and hydroxyproline content of anastomosis in the seventh post-operation. Ghrelin played an effective role on the healing of anastomosis in gastrectomied rats. However, its further mechanism of anastomosis healing is required to be researched in our further studies.

In conclusion, we found that in the early recovery phase in partial gastrectomied rats exogenous ghrelin treatment could increase food intake, body weight and promote the healing of anastomosis. However, ghrelin intervention inhibits the early compensatory roles of ghrelin secretion in the residual stomach simultaneously.

\section{REFERENCES}

Adachi S, Takiguchi S, Okada K, Yamamoto K, Yamasaki M, Miyata H, Nakajima K, Fujiwara $\mathrm{Y}$, Hosoda $\mathrm{H}$, Kangawa K, Mori M, Doki $Y(2010)$. Effects of ghrelin administration after total gastrectomy: a prospective, randomized, placebo-controlled phase II study. Gastroenterol., 138(4): 1312-1320.

Ariyasu H, Takaya K, Tagami T, Ogawa Y, Hosoda K, Akamizu T, Suda M, Koh T, Natsui K, Toyooka S, Shirakami G, Usui T, Shimatsu A, Doi K, Hosoda H, Kojima M, Kangawa K, Nakao K (2001). Stomach is a major source of circulating ghrelin, and feeding state determines plasma ghrelin-like immunoreactivity levels in humans. J. Clin. Endocrinol. Metab., 86(10): 4753-4758.
Asakawa A, Inui A, Kaga T, Yuzuriha H, Nagata T, Ueno N, Makino S, Fujimiya M, Niijima A, Fujino MA, Kasuga M (2001). Ghrelin is an appetite-stimulatory signal from stomach with structural resemblance to motilin. Gastroenterol., 120(2): 337-345.

Brzozowski T, Konturek PC, Sliwowski Z, Pajdo R, Drozdowicz D, Kwiecien S, Burnat G, Konturek SJ, Pawlik WW (2006). Prostaglandin/cyclooxygenase pathway in ghrelin-induced gastroprotection against ischemia-reperfusion injury. J. Pharmacol. Exp. Ther., 319(1): 477-487.

Choi K, Roh SG, Hong YH, Shrestha YB, Hishikawa D, Chen C, Kojima M, Kangawa K, Sasaki S (2003). The role of ghrelin and growth hormone secretagogues receptor on rat adipogenesis. Endocrinol., 144(3): 754-759.

Cowley MA, Smith RG, Diano S, Tschöp M, Pronchuk N, Grove KL, Strasburger CJ, Bidlingmaier M, Esterman M, Heiman ML, GarciaSegura LM, Nillni EA, Mendez P, Low MJ, Sotonyi P, Friedman JM, Liu H, Pinto S, Colmers WF, Cone RD, Horvath TL (2003). The distribution and mechanism of action of ghrelin in the CNS demonstrates a novel hypothalamic circuit regulating energy homeostasis. Neuron., 37(4): 649-661.

Date Y, Kojima M, Hosoda H, Sawaguchi A, Mondal MS, Suganuma T, Matsukura S, Kangawa K, Nakazato M (2000). Ghrelin, a novel growth hormone-releasing acylated peptide, is synthesized in a distinct endocrine cell type in the gastrointestinal tracts of rats and humans. Endocrinol., 141(11): 4255-4261.

de Hingh IH, Siemonsma MA, de Man BM, Lomme RM, Hendriks T (2002). The matrix metalloproteinase inhibitor BB-94 improves the strength of intestinal anastomoses in the rat. Int. J. Colorectal. Dis. 17(5): 348-354.

Dickson SL, Luckman SM (1997). Induction of c-fos messenger ribonucleic acid in neuropeptide $Y$ and growth hormone (GH) releasing factor neurons in the rat arcuate nucleus following systemic injection of the GH secretagogue, GH-releasing peptide-6. Endocrinology, 138(2): 771-777.

Dixit VD, Schaffer EM, Pyle RS, Collins GD, Sakthivel SK, Palaniappan R, Lillard JW Jr, Taub DD (2004). Ghrelin inhibits leptin- and activation-induced proinflammatory cytokine expression by human monocytes and T cells. J. Clin. Invest., 114(1): 57-66.

Dixit VD, Taub DD (2005). Ghrelin and immunity:a young player in an old field. Exp. Gerontol., 40(11): 900-910.

Dornonville de la Cour C, Bjorkqvist M, Sandvik AK, Sandvik AK, Bakke I, Zhao CM, Chen D, Håkanson R (2001). A-like cells in the rat stomach contain ghrelin and do not operate under gastrin control. Regul. Pept., 99(2-3): 141-150.

Dornonville de la Cour C, Lindqvist A, Egecioglu E, Egecioglu E, Tung YC, Surve V, Ohlsson C, Jansson JO, Erlanson-Albertsson C, Dickson SL, Håkanson R (2005). Ghrelin treatment reverses the reduction in weight gain and body fat in gastrectomised mice. Gut, 54(7): 907-913.

Egecioglu E, Stenstrom B, Pinnock SB, Tung LY, Dornonville De La Cour C, Lindqvist A, Hakanson R, Syversen U, Chen D, Dickson SL (2008). Hypothalamic gene expression following ghrelin therapy to gastrectomized rodents. Regul. Pept., 146(1-3): 176-182.

Hameed S, Dhillo WS, Bloom SR (2009). Gut hormones and appetite control. Oral. Dis., 15(1): 18-26.

Hataya Y, Akamizu T, Takaya K, Kanamoto N, Ariyasu H, Saijo M, Moriyama K, Shimatsu A, Kojima M, Kangawa K, Nakao K (2001). A low dose of ghrelin stimulates growth hormone $(\mathrm{GH})$ release synergistically with GH-releasing hormone in humans. J. Clin. Endocrinol. Metab., 86(9): 45-52.

Hosoda H, Kojima M, Matsuo H, Kangawa K (2000). Ghrelin and desacyl ghrelin: two major forms of rat ghrelin peptide in gastrointestinal tissue. Biochem. Biophys. Res. Commun., 279(3): 909-913.

Kamegai J, Tamura H, Shimizu T, Ishii S, Sugihara H, Wakabayashi I (2001). Chronic central infusion of ghrelin increases hypothalamic neuropeptide $Y$ and Agouti-related protein mRNA levels and body weight in rats. Diabetes., 50(11): 2438-2443.

Kamiji MM, Troncon LE, Suen VM, de Oliveira RB (2009). Gastrointestinal transit, appetite, and energy balance in gastrectomized patients. Am .J. Clin. Nutr., 89(1): 231-239.

Kohno D, Nakata M, Maekawa F, Fujiwara K, Maejima Y, Kuramochi M, Shimazaki T, Okano H, Onaka T, Yada T (2007). Leptin suppresses 
ghrelin-induced activation of neuropeptide $Y$ neurons in the arcuate nucleus via phosphatidylinositol 3-kinase- and phosphodiesterase 3mediated pathway. Endocrinology, 148(5): 2251-2263.

Koizumi M, Dezaki K, Hosoda H, Damdindorj B, Sone H, Ming L, Hosoya Y, Sata N, Kobayashi E, Kangawa K, Nagai H, Yasuda Y, Yada T (2010). Reconstruction-dependent recovery from anorexia and time-related recovery of regulatory ghrelin system in gastrectomized rats. Int. J. Pept.

Kojima M, Hosoda H, Date Y, Nakazato M, Matsuo H, Kangawa K (1999). Ghrelin is a growth-hormone-releasing acylated peptide from stomach. Nature, 402(6762): 656-660.

Kojima M, Hosoda H, Kangawa K (2004). Clinical endocrinology and metabolism. Ghrelin, a novel growth-hormone-releasing and appetitestimulating peptide from stomach. Best Pract. Res. Clin. Endocrinol. Metab., 18(4): 517-530.

Kojima M, Kangawa K (2005). Ghrelin: structure and function. Physiol. Rev., 85(2): 495-522.

Konturek PC, Brzozowski T, Konturek SJ, Pawlik M, Gaca P, Hahn EG, Raithel M (2007). Role of histamine in ghrelin-induced gastroprotection against acute gastric lesions. Inflamm. Res., 56(1): S25-26.

Lall S, Tung LY, Ohlsson C, Jansson JO, Dickson SL (2001). Growth hormone $(\mathrm{GH})$-independent stimulation of adiposity by $\mathrm{GH}$ secretagogues. Biochem. Biophys. Res. Commun., 280(1): 132-138.

Liedman B (1999). Symptoms after total gastrectomy on food intake, body composition, bone metabolism, and quality of life in gastric cancer patients--is reconstruction with a reservoir worthwhile? Nutrition, 15(9): 677-682.

Melissas J, Kampitakis E, Schoretsanitis G, Mouzas J, Kouroumalis E, Tsiftsis DD (2002). Does reduction in gastric acid secretion in bariatric surgery increase diet-induced thermogenesis? Obes. Surg., 12(3): 399-403.

Rindi G, Necchi V, Savio A, Torsello A, Zoli M, Locatelli V, Raimondo F, Cocchi D, Solcia E (2002). Characterisation of gastric ghrelin cells in man and other mammals: studies in adult and fetal tissues. Histochem. Cell Biol., 117(6): 511-519.

Shintani M, Ogawa Y, Ebihara K, Aizawa-Abe M, Miyanaga F, Takaya K, Hayashi T, Inoue G, Hosoda K, Kojima M, Kangawa K, Nakao K
(2001). Ghrelin, an endogenous growth hormone secretagogue, is a novel orexigenic peptide that antagonizes leptin action through the activation of hypothalamic neuropeptide $\mathrm{Y} / \mathrm{Y} 1$ receptor pathway. Diabetes, 50(2): 227-232.

Takachi K, Doki Y, Ishikawa O, Miyashiro I, Sasaki Y, Ohigashi H, Murata K, Nakajima H, Hosoda H, Kangawa K, Sasakuma F, Imaoka $S$ (2006). Postoperative ghrelin levels and delayed recovery from body weight loss after distal or total gastrectomy. J. Surg. Res., 130(1): $1-7$

Tang-Christensen M, Vrang N, Ortmann S, Ortmann S, Bidlingmaier M, Horvath TL, Tschöp M (2004). Central administration of ghrelin and agouti-related protein(83-132)increases food intake and decreases spontaneous locomotor activity in rats. Endocrinol., 145(10): 46454652.

Thornton FJ, Barbul A (1997). Healing in the gastrointestinal tract. Surg. Clin. North. Am., 77(3): 549-573.

Toshinai K, Date Y, Murakami N, Shimada M, Mondal MS, Shimbara T, Guan JL, Wang QP, Funahashi H, Sakurai T, Shioda S, Matsukura S, Kangawa K, Nakazato M (2003). Ghrelin-induced food intake is mediated via the orexin pathway. Endocrinol. 144(4): 1506-1512.

Wang HT, Lu QC, Wang Q, Wang RC, Zhang Y, Chen HL, Zhao H, Qian HX (2008). Role of the duodenum in regulation of plasma ghrelin levels and body mass index after subtotal gastrectomy. World $\mathrm{J}$. Gastroenterol., 14(15): 2425-2429.

Wren AM, Small CJ, Ward HL, phy KG, Dakin CL, Taheri S, Kennedy AR, Roberts GH, Morgan DG, Ghatei MA, Bloom SR (2000). The novel hypothalamic peptide ghrelin stimulates food intake and growth hormone secretion. Endocrinol. 141(11): 4325-4328.

Yang J, Brown MS, Liang G, Grishin NV, Goldstein JL (2008). Identification of the acyltransferase that octanoylates ghrelin, an appetite-stimulating peptide hormone. Cell. 132(3): 387-396.

Zhao D, Zhan $\mathrm{Y}$, Zeng $\mathrm{H}$, Moyer MP, Mantzoros CS, Pothoulakis C (2006). Ghrelin stimulates interleukin-8 gene expression through protein kinase C-mediated NF-kappaB pathway in human colonic epithelial cells. J. Cell Biochem., 97(6): 1317-1327. 